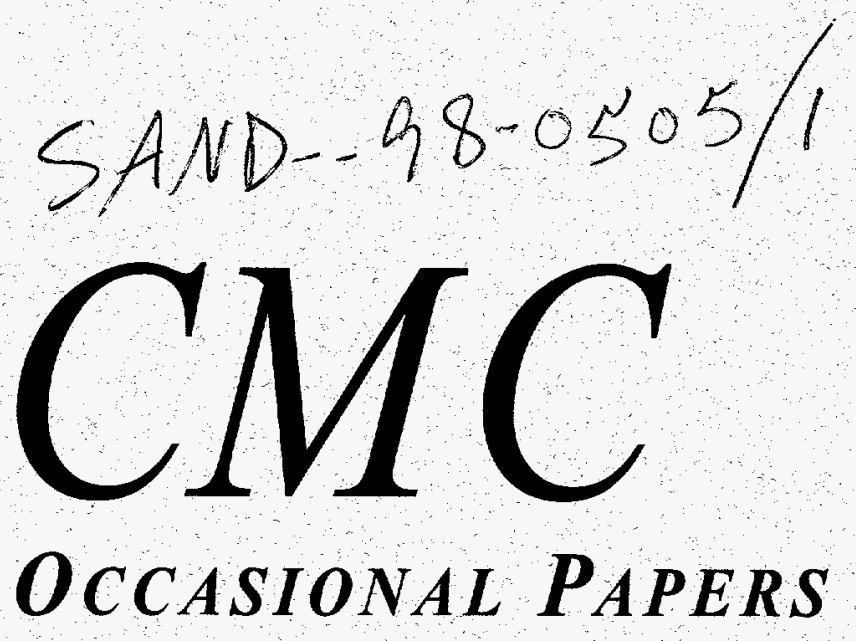

$$
\begin{aligned}
& \text { PES En VSO } \\
& \text { APR } \angle 8998 \\
& \text { USTI }
\end{aligned}
$$

\title{
Freezing the Fighting: Military Disengagement on the Siachen Glacier
}

Samina Ahmed

Consultant, The Asia Foundation,

Islamabad, Pakistan

Varun Sahni

Professor, Jawaharlal Nehru University,

New Delhi, India 
Issued by Sandia National Laboratories, operated for the United States Department of Energy by Sandia Corporation.

NOTICE: This report was prepared as an account of work sponsored by an agency of the United States Government. Neither the United States Government nor any agency thereof, nor any of their employees, nor any of their contractors, subcontractors, or their employees, makes any warranty, express or implied, or assumes any legal liability or responsibility for the accuracy, completeness, or usefulness of any information, apparatus, product, or process disclosed, or represents that its use would not infringe privately owned rights. Reference herein to any specific commercial product, process; or service by trade name, trademark, manufacturer, or otherwise, does not necessarily constitute or imply its endorsement, recommendation, or favoring by the United States Government, any agency thereof, or any of their contractors or subcontractors. The views and opinions expressed herein do not necessarily state or reflect those of the United States Government, any agency thereof, or any of their contractors.

Printed in the United States of America. This report has been reproduced directly from the best available copy:

Available to DOE and DOE contractors from Office of Scientific and Technical Information PO Box 62

Oak Ridge, TN 37831

Prices available from (615) 576-8401, FTS 626-8401

Available to the public from

National Technical Information Service

US Department of Commerce

5285 Port Royal Rd.

Springfield, VA 22161

NTIS price codes

Printed Copy: A03

Microfiche Copy: A01 


\title{
Freezing The Fighting: Military Disengagement On The Siachen Glacier
}

\author{
Samina Ahmed \\ Consultant, The Asia Foundation, \\ Islamabad, Pakistan \\ Varun Sahni \\ Professor, Jawaharlal Nehru University, \\ New Delhi, India
}

\section{Cooperative Monitoring Center Occasional Paper/1}

\section{1i. Sandia National Laboratories}

Sandia is a multiprogram laboratory operated by Sandia Corporation, a Lockheed Martin Company, for the United States Department of Energy under contract DE-AC04-94AL85000.
DISTRIBUTION OF THIS DOCMENT IS UNLIMTEP

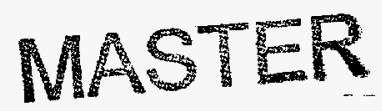


The Cooperative Monitoring Center (CMC) at Sandia National Laboratories assists political and technical experts from around the world to acquire the technology-based tools they need to assess, design, analyze and implement nonproliferation, arms control and other cooperative security measures. As part of its mission, the CMC sponsors research on cooperative security and the role of technology. Reports of that work are provided through the Occasional Papers series. Research is conducted by Sandia staff as well as visiting scholars. The CMC visiting scholars program is administered by the Institute for Public Policy at the University of New Mexico. For additional information on the programs of the $\mathrm{CMC}$, visit the $\mathrm{CMC}$ home page on the World Wide Web at <http://www.cmc.sandia.gov> or write to:

Cooperative Monitoring Center

Sandia National Laboratories

Mail Stop 1373

Albuquerque, NM 87185-1373

For specific information on this report contact:

Kent L. Biringer at the above address.

This report was prepared by Sandia National Laboratories Albuquerque, NM 87185 and Livermore, CA 94550 


\section{DISCLAIMER}

Portions of this document may be illegible electronic image products. Images are produced from the best available original document. 


\title{
Freezing The Fighting: Military Disengagement On The Siachen Glacier
}

\begin{abstract}
Since 1984. India and Pakistan have confronted each other militarily for control over the Siachen Glacier and its approaches in the eastern Karakoram mountain range, adjacent to the borders of India, Pakistan, and China. The longest-running armed conflict between two regular armies in the twentieth century, the conflict in Siachen has resulted in hundreds of casualties, mainly because of adverse climatic conditions and harsh terrain. The economic cost of sustaining a conflict in that geographically remote and climatically inhospitable region has also been extremely high for both countries.

Past efforts by India and Pakistan to find a mutually acceptable solution have failed, mainly because of mutual distrust and suspicion. This paper examines Indian and Pakistani perceptions, preference, and policies, and identifies options for resolving the conflict. This paper also identifies the most appropriate verification and monitoring technologics to assist policy-makers in ensuring agreement stability and compliance. While a future agreement on resolving the dispute will depend, above all, on the political will of the Indian and Pakistani leaderships, adequate, appropriate verification and monitoring mechanisms will enhance their ability to reach a sustainable and durable accord of the Siachen conflict.
\end{abstract}


This page intentionally left blank. 


\section{Contents}

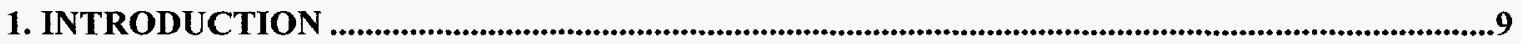

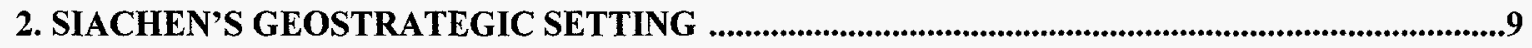

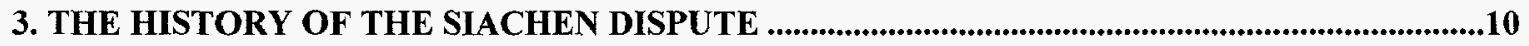

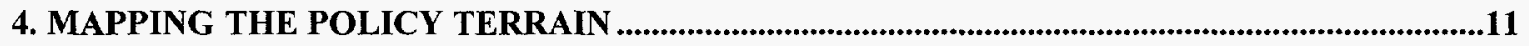

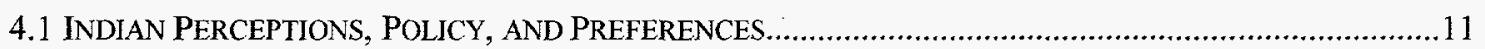

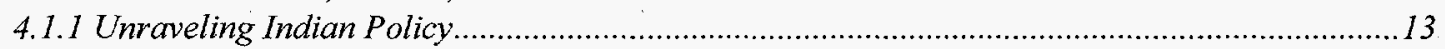

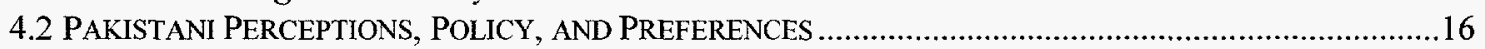

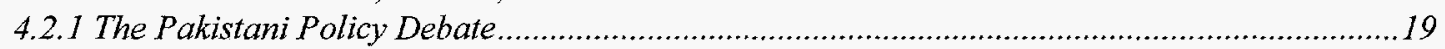

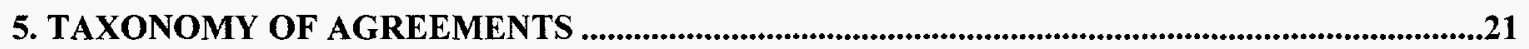

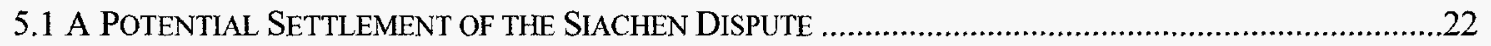

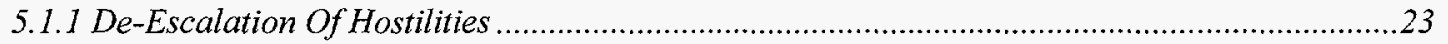

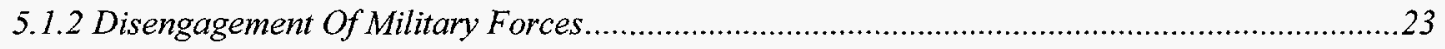

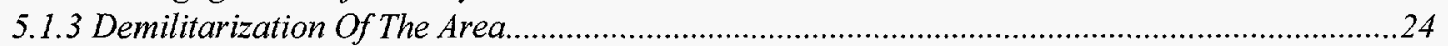

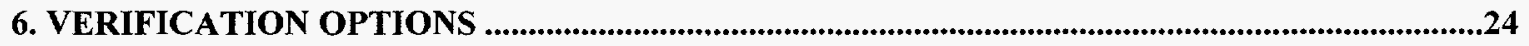

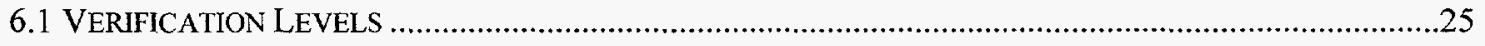

6.1.1 Intrusiveness and Compliance Assurance.........................................................................26

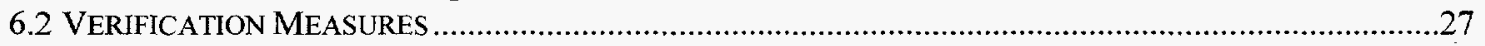

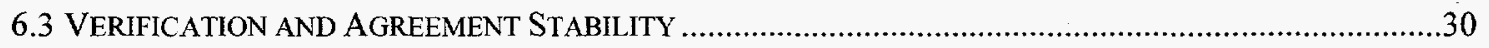

7. FREEZING THE FIGHTING: THE LOGIC FOR CHANGE ..........................................................32

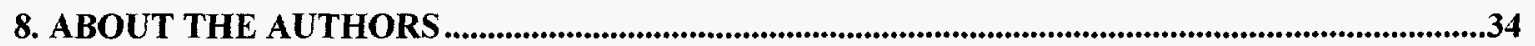

\section{Figures}

Figure 1. Composite Satellite Image of the Siachen Glacier Region..............................12 
Freezing the Fighting:

\section{Acronyms}

CFL Cease-Fire Line

$\mathrm{CMC} \quad$ Cooperative Monitoring Center

LOC Line of Control

POK Pakistan-occupied Kashmir 


\section{Freezing The Fighting: Military Disengagement On The Siachen Glacier}

\section{Introduction}

For over 13 years, Indian and Pakistani troops have confronted each other, eyeball to eyeball, for control of the Siachen Glacier and its approaches in the eastern Karakoram mountain range, adjacent to the borders of India, Pakistan, and China. The conflict has resulted in hundreds of casualties caused by adverse climatic conditions and harsh terrain rather than the occasional military skirmish. In addition, sustaining a conflict in that geographically remote and climatically inhospitable region has a high economic cost.

Indian and Pakistani leaderships acknowledge the human and economic costs of the Siachen conflict. Earlier attempts to reach a mutually agreeable solution have, however, proved unsuccessful. Negotiations on Siachen are again underway as part of an overall peace dialogue between the two states.

Despite the willingness of all involved parties to find a solution to the Siachen dispute, a history of distrust and mutual suspicion derailed earlier efforts. Such hurdles and constraints could, however, be overcome through a variety of measures, including the use of suitable technological mechanisms to verify and monitor a settlement.

By placing the Siachen conflict within its geostrategic and historical setting, this paper examines Indian and Pakistani perceptions, preferences, and policies and identifies options for resolving the dispute. This paper also describes verification and monitoring technologies that can support a future India-Pakistan peace accord on the Siachen Glacier dispute.

\section{Siachen's Geostrategic Setting}

Siachen has witnessed sporadic armed clashes between Indian and Pakistani forces since April 13, 1984. It is by far the longest-running armed conflict between two regular armies in the twentieth century. However, this is not a declared war. India and Pakistan, the two contesting states, continue to maintain full diplomatic relations with each other, and have many other ties, including economic and academic. Neither is this a conventional conflict: although both armies are conventionally armed, weather, altitude, and terrain make this uninhabitable region an unlikely zone of armed strife.

The Siachen Glacier is one of the most inhospitable and glaciated regions in the world. Sliding down a valley in the Karakoram range, the glacier is 76 kilometers long and varies in width between 2 to 8 kilometers. It receives 6 to 7 meters of the annual total of 10 meters of snow in winter alone. Blizzards can reach speeds up to 150 knots (nearly 300 kilometers per hour). The temperature drops routinely to 40 degrees $\mathrm{C}$ below zero, 
and even lower with the wind chill factor. For these reasons, the Siachen Glacier has been called the "Third Pole."

This misleading epithet focuses solely on the adverse weather conditions and completely ignores the deleterious impact of altitude and terrain. In reality, the high altitude severely compounds the bitter climatic conditions. Base Camp for Indian forces is 12,000 feet above sea level. The altitude of some Indian forward bases on the Saltoro Ridge ranges from Kumar (16,000 feet) and Bila Top (18,600 feet) to Pahalwan (20,000 feet) and Indira Col (22,000 feet). Because of the steep gradient of the Saltoro Range, the area is also prone to avalanches. These adverse conditions have direct consequences: since the war began, only 3 per cent of the Indian casualties were caused by hostile firing. The remaining 97 per cent have fallen prey to the altitude, weather, and terrain.

Pakistani combat casualties are equally low because troops are dug in, artillery fire over mountain peaks is generally inaccurate, and infantry assaults are seldom made in the harsh climate and difficult terrain. Most Pakistani casualties occur because of the climate, terrain, and altitude. Pakistani positions are, for the most part, at a lower altitude in the glacier area, ranging between 9,000 to 15,000 feet (some are at a much higher altitude such as Conway Saddle, at 17,200 feet, which controls ingress to the glacier). Glaciers at the Pakistani frontlines begin at 9,440 feet. Pakistani troops are stationed on steep slopes, exposed to harsh weather. As a result, the main causes of Pakistani casualties are treacherous crevasses and ravines, avalanches, high altitude pulmonary and cerebral edema, and hypothermia. ${ }^{1}$

\section{The History Of The Siachen Dispute}

The fight for the Siachen Glacier involves territory claimed by both states but not controlled by either until the mid-1980s. The origins of this armed conflict lie in the India-Pakistan dispute over the state of Jammu and Kashmir. In 1948, following an inconclusive war, the areas of the disputed state that fell under Pakistan were comprised of the Northern Areas (Baltistan and Gilgit Agency), Azad Jammu, and Kashmir. India controlled two-thirds of the territory including Jammu state, Ladakh, and the valley of Kashmir.

A Cease-Fire Line (CFL) was established as a result of the 1949 India-Pakistan agreement that concluded the war in Kashmir. The CFL ran along the international IndiaPakistan border and then north and northeast until map grid-point NJ 9842, located near the Shyok river at the base of the Saltoro mountain range. Because no Indian or Pakistani troops were present in the geographically inhospitable northeastern areas beyond NJ 9842, the CFL was not delineated as far as the Chinese border. Both sides agreed, in the

\footnotetext{
1 According to a Pakistani officer stationed in Siachen, "We have lost many more men to avalanches, crevasses and cold than we have to shells and bullets." Muhammad Mujeeb Afzal, "Siachen," The News, April 12, 1995.
} 
vague language that lies at the root of the Siachen dispute, that the CFL extends to the terminal point, NJ 9842, and "thence north to the glaciers.".

After the 1965 India-Pakistan war, the Tashkent agreement resulted in troop withdrawals to positions along the $1949 \mathrm{CFL}$. No attempt was made to extend the CFL further. Following Pakistan's defeat in the 1971 war, the Simla Agreement of 1972 established a new Line of Control (LOC) as a result of the cease-fire of December 1971. The Siachen Glacier region. where no fighting had taken place, was left undelineated, and no attempt was made to clarify the position of the LOC beyond NJ 9842. The LOC was merely described as moving from Nerlin (inclusive to India), Brilman (inclusive to Pakistan), up to Chorbat La in the Turtok sector. "From there the line of control runs northeastwards to Thang (inclusive to India) thence eastwards joining the glaciers."3

Since the Siachen Glacier region falls within the undelineated territory beyond the last defined section of the LOC, map grid-point NJ 9842, India and Pakistani territorial claims are based on their interpretations of the vague language contained in the 1949 and 1972 agreements. Pakistan draws a straight line in a northeasterly direction from NJ 9842 up to the Karakoram Pass on its boundary with China. ${ }^{4}$ India instead draws a northnorthwest line from NJ 9842 along the watershed line of the Saltoro Range, a southern offshoot of the Karakoram Range. ${ }^{5}$ Figure 1 shows the disputed area and each country's claim lines.

\section{Mapping the Policy Terrain}

Any attempt to analyze the Siachen dispute and identify potential opportunities and mechanisms for its resolution involves not only mapping the geographical dimension but also mapping the policy terrain of the two disputant states. An analysis of Indian and Pakistani perceptions is equally essential since such perceptions shape policies and preferences in both countries.

\subsection{Indian Perceptions, Policy, and Preferences}

From an Indian perspective, the Siachen Glacier is the wedge of territory that separates Pakistan-occupicd Kashmir (POK) from Aksai Chin, the part of Kashmir claimed and

\footnotetext{
${ }^{2}$ Robert G. U irsing. "The Siachen Glacier Dispute-I: The Territorial Dimension," Strategic Studies (Vol. X, No. 1, Autumn 1986), p. 51.

${ }^{3}$ Details of the Line of Control provided to the Indian parliament by Indian Foreign Minister, Sardar Swaran Singh in December 1972. Cited in A.G. Noorani, "Fire on the Mountain," Illustrated Weekly of India, June 30. 1985, p. 40.

${ }^{4}$ Ikram Sehgal, “The Siachen Battleground: Withering Heights," Globe (Nos. 10 and 11, 1996), p. 67. See also Robert Wirsing, op.cit., pp. 60-61.

${ }^{5}$ Jasjit Singh, "Siachen Glaciers: Facts and Fiction," Strategic Analysis (Vol. XII, No.8, October 1989), pp. 700-701; W.P.S. Sidhu, "They Shall Not Pass," India Today, May 31, 1992, p. 90.
} 


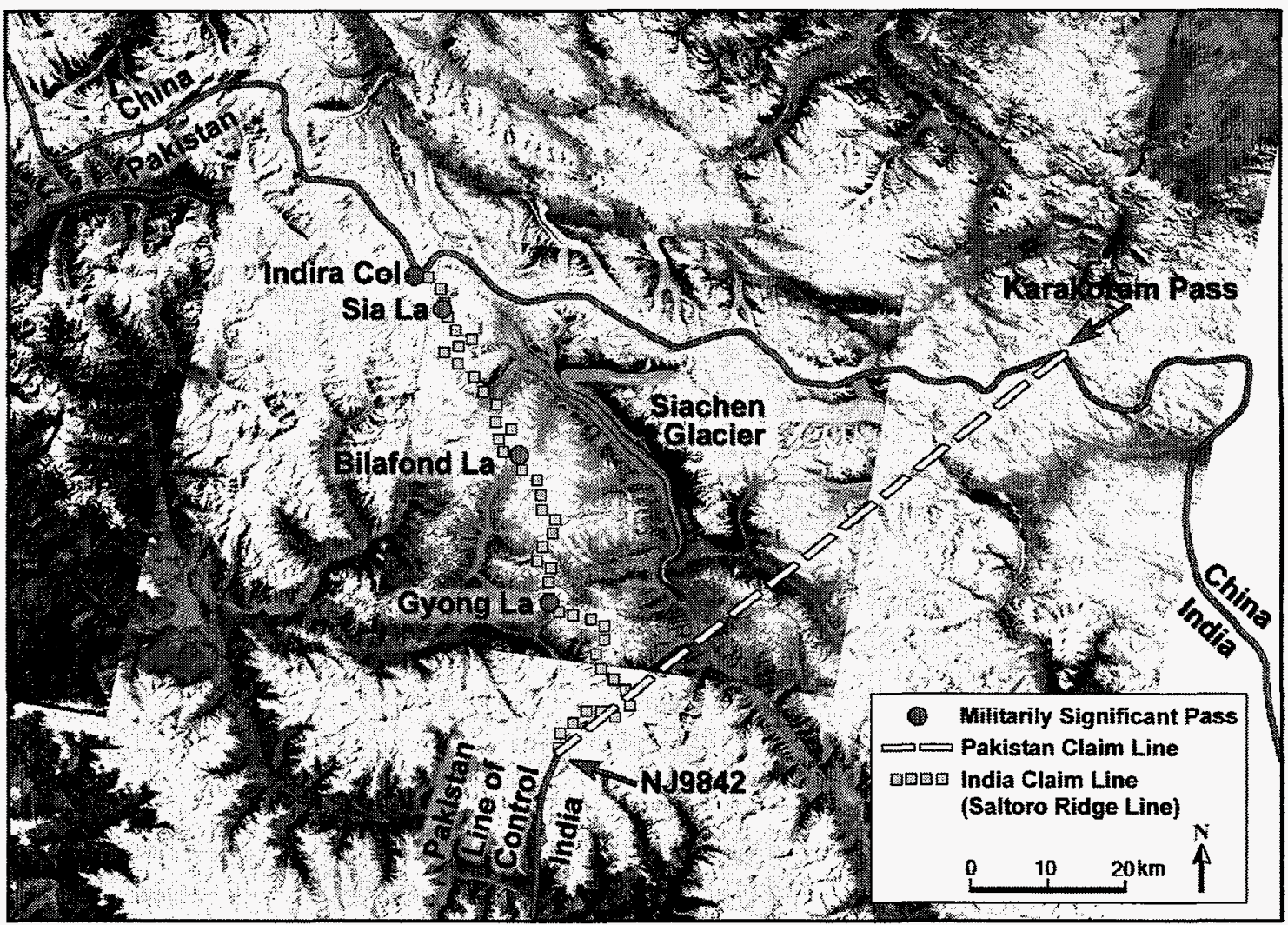

Figure 1. Composite Satellite Image of the Siachen Glacier Region ${ }^{6}$

occupied by China. ${ }^{7}$ In Indian perceptions, Siachen's geostrategic importance lies in the fact that its control would support Indian defense of Ladakh, Jammu, and Kashmir against Pakistani and/or Chinese threats. ${ }^{8}$ It would prevent the outflanking of Indian forces in Leh and Kargil sectors and connecting the Aksai Chin highway with the Karakoram pass. Control over Siachen would enable India to keep watch over the Karakoram highway and the Khunjarab pass, while fortifying India's position in border negotiations with China. ${ }^{9}$

\footnotetext{
${ }^{6}$ Image processing by Earth Data Analysis Center, University of New Mexico.

${ }^{7}$ Indian commentators emphasize that Siachen is, in the words of General Chibber, "the wedge that keeps our two adversaries apart." Lt. Gen. M.L. Chibber, "Siachen-The Untold Story (A Personal Account)," Indian Defence Review, January 1990, p. 146. See also P.M. Pasricha, "The Siachen Glacier-An Orographic Offensive by Pakistan," Strategic Analysis, December 1985, p. 855 and Rita Manchanda, "Indo-Pak 'Mountain Diplomacy"," The Telegraph, June 9, 1985.

${ }^{8}$ Yusuf Jameel, "India Ready Even for Sino-Pak Offensive," The Telegraph, 23 June 1985; Lt. Col. Daljit Singh, "The Long War," The Illustrated Weekly of India, April 9, 1989 and Yusuf Jameel, "On the World's Highest Battleground," The Telegraph, May 12, 1989.

${ }^{9}$ Rita Manchanda, op.cit.
} 
For India, controlling the commanding heights is a crucial aspect of the Siachen conflict. This issue flows out of basic infantry tactics: height confers a tactical advantage. ${ }^{10}$

Except at Gyong La, Indian forces occupy and control the commanding heights. Thus, Pakistani military efforts since 1984 have been aimed at dislodging Indian forces from their positions. This strategy puts Pakistan at a distinct disadvantage for two reasons: (1) Pakistani forces have to carry the assault to the Indians, who have a much easier military task of sitting tight and defending their positions; and (2) that assault requires Pakistani forces to climb steep terrain. ${ }^{11}$

On the other hand, as long as Pakistan does not commit its forces to an offensive against the Indian positions, it is the Indians who have the disadvantage of being deployed at much higher altitudes. In order to block Pakistan's access to the Siachen Glacier, India has no option but to maintain its hazardous posts on the Saltoro Ridge, thereby exposing its forces to the dangerous altitude, weather, and terrain. India's strategy is also extremely expensive in financial terms: most of the Indian pickets and posts on the Saltoro Ridge are air-maintained. Personnel, weapons, ammunition, fuel, and food are usually flown in by helicopter, and occasionally paradropped. ${ }^{12}$

\subsubsection{Unraveling Indian Policy}

India's declared policy on the Siachen dispute is to interpret "thence northwards to the glaciers" to mean that the LOC proceeds from NJ 9842 along the watershed line of the Saltoro range. ${ }^{13}$ However, India's declared policy is not a sufficient indicator of the

\footnotetext{
${ }^{10}$ According to General Chibber, the notion that "reasonably well-prepared defensive positions could not be dislodged" was basic to the Indian concept of operations. He argues that "at these formidable altitudes it is difficult, almost impossible, to dislodge a force that occupies a height." Lt. Gen. Chibber, op.cit, pp. 150151.

${ }^{11}$ Over the years, many Indian analysts have emphasized the importance of Indian control of the Siachen heights. See, for example, Srijoy Chowdhury, "Glacier of Discontent," Sunday, October 20-26, 1985; Preeti Singh, "Pakistani Eyes on Siachen Glacier," Patriot, August 31, 1985; O.P. Sabherwal, "Siachen: Snow-bound Frontier," Mainstream, June 22, 1985; Raj Chengappa, "Siachen Glacier: Battle of the Heights," India Today, December 31, 1987; Manoj Joshi, "Siachen: Face to Face," Frontline, October 1, 1988 and Man Mohan, "India Frustrates Pakistani Pressure on Siachen Glacier," The Hindustan Times, August 23, 1992.
}

${ }^{12}$ As M.J. Akbar remarks, "India's problems are greater than Pakistan's because the latter's supply lines need mules; ours need helicopters." M.J. Akbar, "Fresh Bid for End to Siachen War," The Telegraph, August 20, 1992. See also Joydeep Sircar, "India is on High Ground at Siachen," The Telegraph, October 25, 1985 and M.K. Dhar, "More Incursions in Siachen Likely," The Hindustan Times, October 4, 1987.

13 Air Commodore Jasjit Singh points out that "in mountainous terrain, the high crest line marking the watershed is the internationally accepted norm for working out boundary settlements, much as the thalweg (or the mid-channel) riverine principle is used to delineate boundaries along rivers." Air Commodore Jasjit Singh, "The Siachen Imperatives," The Hindu, July 13, 1989. In another article, Singh argues that the watershed principle is extremely important in Siachen because "any deviation by India from this principle would have a major implication for the settlement of the Sino-Indian border where India's position is premised on this principle." Air Commodore Jasjit Singh, "Siachen: The Himalayan Battlefield," The Hindustan Times, October 18, 1987. 
different perspectives, concerns, and objectives in the Indian policy community on the Siachen dispute. Three alternatives are readily discernible in India: (1) maintaining the deployment on Siachen at all costs, (2) negotiating a military disengagement with Pakistan, and (3) withdrawing Indian forces from the glacier, unilaterally if necessary.

The advocates of a negotiated or unilateral Indian withdrawal base their position on several arguments. They argue that the disputed region is uninhabitable, and therefore has no strategic value. Some believe that a Siachen settlement could be the first step in the resolution of the Kashmir dispute. ${ }^{14}$ Others argue that the Kashmir and Siachen disputes can be unlinked, and that Siachen can be resolved without compromising on Kashmir. They hold that the Saltoro range is a killing field, and the much higher altitude of the Indian posts exacerbates India's problems. They argue that the financial costs of India's Siachen operations represent a huge waste of much-needed resources. ${ }^{15}$ Most important of all, they feel that the Siachen conflict is a cruel, costly, and unnecessary war that must be brought to an end. ${ }^{16}$

While many of the above views are valid, they do not represent the predominant Indian perspective on Siachen. Indeed, the very fact that the advocates of withdrawal are already convinced that a resolution of the conflict is desirable and possible makes them less important than the sector of opinion that opposes withdrawal but would consider a compromise provided certain conditions are met.

The opponents of an Indian withdrawal from Siachen argue that the glacier has strategic value to India because it physically separates Pakistan and China, the country's primary adversaries. Furthermore, a Siachen withdrawal would weaken India's position on Kashmir. ${ }^{17}$ Control of the commanding heights gives India the tactical advantage and denies Pakistan access to the glacier. India should therefore not relinquish its battlefield gains on the negotiating table, because Pakistan would occupy the heights as soon as

\footnotetext{
${ }^{14}$ See in particular A. G. Noorani, "Easing the Indo-Pakistani Dialogue on Kashmir: Confidence-Building Measures for the Siachen Glacier, Sir Creek and the Wular Barrage Disputes," Occasional Paper I6 (The Henry L. Stimpson Center, Washington DC, April 1994).

${ }^{15}$ The actual amount spent by India on the Siachen operation is almost impossible to ascertain since it is buried under more than a dozen budget heads. Figures in journal articles and newspaper reports vary enormously and are deemed unreliable.

${ }^{16}$ W.P.S. Sidhu, for instance, calls it a "war of prestige" and a "crime against humanity." W.P.S. Sidhu, "Siachen: The Forgotten War," India Today, May 31, 1992, p. 88.

${ }^{17}$ Lt. Gen. Chibber expresses the view that "the whole of Jammu and Kashmir belongs to India; so where is the need for compromise?" In a similar vein, Air Commodore Jasjit Singh argues that "the issues related to the Siachen glacier constitute only a subset of a larger dispute. . concerning the state of Jammu and Kashmir. . The fundamental issue here is not a border/territorial dispute. . . in the sense it would have been if the area held by Pakistan across the Indian defense line on the Saltoro range was Pakistani territory." Lt. Gen. Chibber, op.cit, p. 151; Air Commodore Jasjit Singh, "Far From a Thaw: What Blocks a Full Settlement," Frontline, December 4, 1992.
} 
India withdrew from them. ${ }^{18}$ As for the human cost, because Indian military personnel are volunteers, casualties are not a sufficient reason to withdraw. In any case, only a small part of the Indian army is deployed on the Saltoro Range, and over the years the Indian forces have learned how to engage in glacial warfare. ${ }^{19}$ Although the financial cost is significant, India has already borne this financial burden for 13 years and could continue to do so indefinitely.

Subtle distinctions are important among Indian analysts and policy makers who oppose a withdrawal of Indian forces from their current deployment on the Saltoro Range. Some are convinced that India must hold on to Siachen at all costs. They argue that Pakistan is conducting a highly successful low-cost proxy war in Kashmir, at considerable cost to India. The only theater in which India is able to pay Pakistan back in its own coin is on the Siachen Glacier itself, where India has a distinct tactical advantage. No matter what the cost, India must therefore stand firm. Any compromise on Siachen would relieve the pressure on Pakistan in the one place where it really hurts and would thus be tantamount to falling into a Pakistani trap.

Another hardline position is that India must not withdraw from Siachen because it represents a major military victory for India. India won the race for the glacier, and now controls the commanding heights on the Saltoro range. Over the last 13 years, Pakistan has tried innumerable times to displace the Indian forces, and has always had to withdraw with severe casualties. India has to do nothing but sit tight and periodically repel a Pakistani assault. Any Indian withdrawal will leave Pakistan with an open door to the commanding heights. Pakistan would gain in a negotiation what it has been unable to obtain on the battlefield. Whatever the cost, India must therefore stand firm and maintain its current deployments.

The viewpoints articulated above may appear equally hawkish, with neither willing to countenance an Indian withdrawal from the Saltoro heights. However, a closer look reveals significant differences between them. No agreement with Pakistan that involves an Indian withdrawal would ever satisfy the policy makers and analysts for whom the real value of Siachen is that it is a bleeding ground for Pakistan. In contrast, a resolution can be devised to meet the principal concerns of Indian policy makers and analysts opposed to a Pakistani occupation of the Saltoro heights and Siachen following an Indian withdrawal. This group would back a negotiated Indian withdrawal provided they were convinced that India could, with adequate warning, forestall any Pakistani attempt to move into positions India vacated.

\footnotetext{
${ }^{18}$ According to Mahendra Ved, for example, "Positions gained and maintained after fierce fighting cannot be given away through talks, since there is no guarantee who will violate the pact and regain more than what was in their possession earlier." Mahendra Ved, "Siachen Talks Aim is Status Quo," The Hindustan Times, May 30, 1989.

${ }^{19}$ See, for example, IDR Research Team, "Glacial Warfare: The Indian Army Experiences a New Dimension in High-Altitude Warfare," Indian Defence Review, July 1989, p. 96.
} 
The key to an agreement on the Indian side would lie in convincing as many hardliners as possible within the Indian policy-making community that an Indian withdrawal would not be tantamount to handing Siachen over to Pakistan. This implies that the Indian army, the only government agency with the professional competence to assess military strategy, would have a major say, virtually amounting to a veto, on any Siachen agreement. In terms of Indian policy making, the Siachen issue is thus extremely unusual, because ordinarily the military institutions in India are firmly subordinated to civilian authority. However, the memory of defeat at the hands of China in 1962 is very much alive in India, and no politician or bureaucrat is likely to interfere in matters of professional military judgment. Thus, the army's assessment of the military implications of a Siachen agreement would be critical to whether or not India accepted the agreement.

\subsection{Pakistani Perceptions, Policy, and Preferences}

In Pakistani perceptions, the Siachen dispute has a relevance to the dispute with India over Kashmir, albeit an indirect one. Because of the hostile nature of the terrain, negotiators responsible for delineating the 1949 India-Pakistan cease-fire line in the disputed territory of Kashmir left an undefined area which encompassed the Siachen Glacier and its approaches. After the India-Pakistan wars of 1965 and 1971, neither state attempted to delineate a cease-fire line or line of control in the Siachen region because of the nature of the terrain and the absence of any physical military presence. ${ }^{20}$

Pakistan interprets the vague language contained in the 1972 Simla agreement to mean that the LOC should extend in a straight line in a northeasterly direction from NJ 9842 toward the Karakoram Pass. At the same time, Pakistan recognizes the disputed nature of the Siachen region. In the 1963 Sino-Pakistan agreement, for example, in which the Karakoram Pass was defined as the terminal point for the delineation of the Sino-Pakistan international boundary, the areas south of the border were described as "the contiguous areas the defense of which is under the actual control of Pakistan," and not as Pakistani territory. ${ }^{21}$

Pakistan also claims that the Siachen Glacier and its approaches fall within the Pakistanicontrolled and administered territory of Jammu and Kashmir, more specifically in the Baltistan district in the Northern Areas. ${ }^{22}$ The claim that Siachen is a part of Pakistan's Northern Areas is significant because Pakistan has, since independence, gradually

\footnotetext{
${ }^{20}$ Ibnul Hasan, "Siachin: No Breaking of the Ice Yet," The Pakistan Times, June 23, 1986; Ikram Ullah, "The Truth About Siachen Glacier-II: Why Should Pakistan Bite the Bait?" ibid., October 20, 1987. The Pakistan Times, a daily newspaper, has served as the unofficial organ of the Pakistan government.

${ }^{21}$ Robert G. Wirsing, "The Siachen Glacier Dispute-II: The Strategic Dimension," Strategic Studies (Vol. XII, No. 1, Autumn 1988), pp. 45-46.

${ }^{22}$ Pakistani analysts claim that the Siachen Glacier has been a "de facto and de jure part of Pakistan's Northern Areas ever since the creation of the ceasefire line." See Shabbir Hussain, "Siachen Glacier-Facts and Fiction," The Pakistan Times, September 6, 1985, and A. Sayeed Khan Qamar, "Siachen Glacier-A Test of Indian Political Sagacity," The Muslim, June 9, 1986.
} 
incorporated the Northern Areas within the state. ${ }^{23}$ Pakistani officials have also taken the stand that the Northern Areas were never under the direct jurisdiction of the state of Jammu and Kashmir in undivided India. ${ }^{24}$ While no steps have been taken, so far, to integrate the Northern Areas formally within Pakistan, such a move is possible in the future. ${ }^{25}$ The anomalous status of the Northern Areas provides Pakistan the justification, when the need arises, to separate the Siachen conflict from the larger dispute over Kashmir. Siachen is thus portrayed as a regional issue by Pakistani officials as opposed to Kashmir, which, it is stressed, is an international issue. ${ }^{26}$

Although the dispute over the Siachen region is recognized as a by-product of partition, because the area was left undelineated, all Pakistani governments have claimed permanent administrative control over this "subdistrict" of Baltistan. They also claim that Pakistani administrative control has international recognition. For example, international mountaineering expeditions to the vicinity of the Siachen Glacier have obtained permission from Pakistani authorities since the $1950 \mathrm{~s} .{ }^{27}$ Cartographic international recognition for Pakistani territorial claims is also cited, including several international atlases that show the Siachen Glacier as lying well within the Pakistanicontrolled portions of the LOC. ${ }^{28}$

Pakistan admits, however, that its claims to administrative control did not translate into actual physical presence. No permanent posts were established due to the inhospitable

${ }^{23}$ Unlike Azad Jammu and Kashmir, which has, at least in official terms, a separate state structure, the Northern Areas are under the direct administrative control of the Pakistan federal government.

${ }^{24}$ Challenging India's claim that the Siachen area was a part of Jammu and Kashmir, Pakistani Foreign Minister, Sahabzada Yaqub Khan, claimed that the Glacier was an integral part of Pakistan's Northern Areas, which had historically fallen outside the boundaries or administrative control of Jammu and Kashmir state. Brig (retd.) A.R. Siddiqi, "Siachen: The Glacier Won't Move," Dawn, June 30, 1986.

${ }^{25}$ On August 28, 1997, the Federal Minister for Kashmir Affairs and Northern Areas, Lt. Gen. Majeed Malik declared that the federal government intends to decide the future of Gilgit and Baltistan, keeping in mind the claim of the people of the Northern Areas that their region was not a part of Jammu and Kashmir and that "they liberated the areas by themselves and struck a willed accession with Pakistan." Dawn, August 29, 1997.

${ }^{26}$ Pakistan Foreign Office sources cited in Aroosa Alam, "Siachen Likely to be Demilitarized," The Muslim, December 7, 1993. Announcing Pakistan's willingness, in March 1997, to resume talks on demilitarizing Siachen, Foreign Office spokesman Khalid Saleem stated that: "The Siachen situation is not directly linked to Kashmir." Umer Farooq, "Pakistan Ready to Discuss Withdrawal from Siachen," The Nation, March 2, 1997.

${ }^{27}$ According to Pakistani sources, as early as 1957 , a British expedition sought Pakistani permission to visit the glacier zone. Since the 1972 Simla agreement, over 20 international mountaineering expeditions had sought similar permission from Pakistani authorities. Dr. Muhammad Aslam Sheattles, "From Cochin to Siachen," The Pakistan Times, December 15, 1992; I.A. Iftikhar, "Siachen: India's Achilles Heel," The Muslim, April 18, 1995.

${ }^{28}$ These include the National Geographic Society's Atlas of the World, the University of Chicago's A Historical Atlas of South Asia, The Times Atlas of the World and the 1981 and 1982 issues of the American Alpine Journal. 
terrain and harsh climatic conditions. ${ }^{29}$ Pakistan was willing to accept the territory as noman's land until India deployed its forces in the Siachen area in 1984. By Pakistani perceptions, this violated the spirit of the Simla Agreement according to which neither side would resort to the use of force to resolve bilateral disputes. ${ }^{30}$

The Indian military made substantive gains, acquiring control over two of the three key mountain passes in the Saltoro Range. The initial Pakistani response was to simultaneously contain the Indian advance and to dislodge Indian troops from their positions on the higher ground in the passes providing access to the glacier. By controlling the heights, the Indians were in a militarily advantageous position. The Pakistani offensives failed and there were high casualty rates. ${ }^{31}$ Since then, Pakistani strategies, tactics, and goals have been reassessed.

While artillery, rockets, and gunfire put pressure on Indian troops, large-scale offensives are no longer mounted against Indian positions on the more easily defensible high mountain passes. Instead, Pakistan's military planners have used and consolidated their advantages over their Indian adversaries in terms of terrain, altitude, and logistics. While Pakistani troops are stationed outside the glacier, in less forbidding terrain than their Indian adversaries, the Pakistani military presence forces India to retain its troops on the more elevated and hazardous mountain passes, resulting in higher attrition rates because of the dangerous altitude, weather, and terrain. ${ }^{32}$

Logistically, Pakistan controls Gyong La, which sits astride India's access route from Leh to the glacier and its approaches. Pakistani troops are only twenty kilometers away from

\footnotetext{
${ }^{29}$ Addressing Parliament in November 1985, Pakistani Minister of State for Foreign Affairs Zain Noorani declared that "the glacier up to the Karakorum Pass" was "under Pakistan's administrative control." $\mathrm{He}$ added, "No troops had, however, been posted there (prior to 1984) because of climatic conditions." Maleeha Lodhi, "Siachen: What Really Happened?" The Muslim, October 22, 1987.

${ }^{30}$ In an interview with an Indian news agency, Prime Minister Benazir Bhutto pointed out that the Siachen conflict was "the first and only instance of violation of the Simla Agreement," adding that Pakistan sought to resolve it peacefully "in accordance with the Simla Agreement, in which both sides are committed to not alter the situation unilaterally." The Hindustan Times, June 20, 1989. See also M.H. Askari, "Unfreeze Siachen?" Dawn, November 18, 1987.

${ }^{31}$ Pakistani sources claim that 100 to 160 Pakistanis were killed in the September 1987 abortive bid by a full battalion to capture Indian positions on the higher ground near Bilafond La. Indian sources claim that more than 250 Pakistanis were killed in the offensive. The Nation, 7 October 1987; 10 October 1987; M.J. Akbar, "Top Secret Pak File on Siachen Leaked to India on Eve of Critical Battle," The Telegraph, January 1, 1988.

${ }^{32}$ In Pakistani estimates, Indian expenditure on the Siachen operations is five times higher, while the casualty ratio is 10 to one. Lt. Gen. Imranullah Khan, who served as Corps Commander, responsible for Siachen, claims: "Our aim has been to make it expensive for them, and that has worked." E.A. Bokhari, "The Queen of Glaciers," Globe (Nos. 2 and 3, 1997), p. 70. See also Aroosa Alam, op.cit.
} 
a main Indian supply route at Dzingrulma. ${ }^{33}$ The Pakistani military, on the other hand, has easier land access to its posts through Pakistani-controlled territory. Since the mid-1980s continuous improvements of Pakistani logistical/administrative support and ground communications have been made as roads and tracks have been brought up to the Pakistani lower base camps. ${ }^{34}$ As a result, Pakistan's casualty rates and financial costs have decreased, in sharp contrast to India, which is forced to provide all logistical support by air to its forces.

\subsubsection{The Pakistani Policy Debate}

Strategically, Pakistan continues to focus on its primary objective of driving the costs of the Siachen dispute high enough to force India to make concessions in any future settlement. Declared policy in Pakistan is equally consistent. The Siachen Glacier and its approaches are located within Baltistan in the Pakistani-administered Northern Territories. Pakistan will not accept the status quo on Siachen because India's military presence on the glacier and its environs is illegal. ${ }^{35}$

Pakistani policy makers have, however, demonstrated a certain flexibility on the Siachen issue, which is missing in the India-Pakistani dialogue on the larger dispute of Jammu and Kashmir. Pakistan's refusal to negotiate its basic demand for a plebiscite on Kashmir contrasts sharply with its willingness to consider measures ranging from redeployment to demilitarization regarding the Siachen dispute. Officials and opinion-makers recognize that the Siachen dispute focuses on territory of little strategic value, while draining funds, manpower, and military hardware. ${ }^{36}$

\footnotetext{
${ }^{33}$ A.G. Noorani, "CBMs for the Siachen Glacier, Sir Creek, and Wular Barrage," Michael Krepon and Amit Sevak (eds), Crisis Prevention, Confidence Building and Reconciliation in South Asia (Manohar, New Delhi, 1996), p. 88.

${ }^{34}$ The 150-kilometer track between Baltistan's district headquarters Skardu and Dansam, the first of a series of Pakistani military base headquarters for the Siachen Glacier region, has been developed into a wide road, capable of handling heavy vehicles. A field mess and hospital have been established at a further base, Goma. Roads and bridges have also been constructed between Goma and Gyari, where the glaciated region begins. See Lt. Col. Syed Ishfaq Ali, "Scaling the Heights of Siachen," The Nation, July 2, 1991. See also Ikram Sehgal, op.cit,, p. 69; Zahid Hussain, "Fighting on the Roof of the World," The Muslim, June 22, 1991, and Shahjehan, "Closer to Heaven," The News, April 25, 1996.

${ }^{35}$ Discussing the outcome of the sixth round of defense secretaries' talks on Siachen, Pakistan's Minister for Foreign Affairs Siddique Khan Kanju, told the Senate on February 22, 1993, that India had illegally occupied the Siachen Glacier in 1984, in contravention of the Simla Agreement; adding that Pakistan's willingness to negotiate the issue did not imply a recognition of Indian ground claims. The Frontier Post, February 23, 1993.

${ }^{36}$ Questioning the rationale behind the fighting in the Siachen, Pakistani Foreign Secretary Shahryar Khan stated, "Why should we be facing each other on the roof of the world? It's stupid - two nations locked in totally futile combat." Molly Moore, "Siachen Glacier Winning War," Dawn, May 4, 1993. See also The Nation, October 3, 1992.
} 
Tracing the course of the conflict and the negotiating behavior of Pakistani policy makers, it is clear that a unilateral Pakistani withdrawal can be ruled out because Indian forces control most of the glacier's territory, including the high ground on two of its three major passes. There are three policy options before Pakistani decision-makers: (1) to continue the armed conflict, (2) to sign an agreement limited to conflict containments, or (3) to reach a comprehensive and permanent settlement with India. The adoption of any of these options depends on the perceptions, preferences, and bargaining power of various sections of Pakistan's policy-making community.

Hardline elements, including influential segments within Pakistan's military establishment and civil bureaucracy, favor a continuation of the conflict because India is perceived as the aggressor. ${ }^{37}$ For this segment of Pakistani opinion, a negotiated settlement is regarded as an unnecessary concession. The military stalemate is seen as favoring Pakistan because neither side can claim to have ousted the other from the disputed territory. A more important motive for continuing the conflict is the desire to avenge the initial Pakistani military reverses by seeing India bleed because India's human and financial costs are far higher. ${ }^{38}$

More moderate elements within the political leadership as well as in the civil-military bureaucracies favor a negotiated settlement. ${ }^{39}$ Moderate elements believe that Pakistani casualties and the economic burden do not justify sustaining a conflict over an inhospitable territory with no population or resources and little geostrategic value. ${ }^{40}$ Even among Pakistani supporters of a negotiated settlement, however, there are concerns, based on a history of mistrust, that India would attempt to use a settlement to legitimize its claim over the disputed area. ${ }^{41}$

37 "Every square inch is sovereign territory," declared the head of the Pakistan armed forces' Inter-Services Public Relations, Major General Jehangir Nasrullah. "You can't throw it away." Molly Moore, op.cit.

${ }^{38}$ According to some senior Pakistani army officers, "They (the Indians) asked for it, and let them pay for it." Air Marshal (retd.) Ayaz Ahmed Khan, "Siachen: The Graveyard of Indian Army," Defence Journal (Vol. XXI, Nos. 5-6), p. 37.

${ }^{39}$ Announcing the resolve of the Nawaz Sharif government to maintain "normal good neighborly relations with India," Foreign Office spokesman Khalid Saleem declared that: "We are always willing to discuss the question of withdrawing troops from Siachen provided it is based on agreements and agreed principles." Tariq Butt, "Pakistan ready to discuss withdrawal from Siachen," The News, March 2, 1997.

${ }^{40}$ Pakistan Foreign Secretary Shahryar Khan disclosed that each 'roti' (piece of bread) for Pakistani soldiers in Siachen costs more than Rs 450 (approximately US \$10). The Nation, December 29, 1987; The News, August 23, 1992.

${ }^{41}$ Pakistan has rejected any Indian claim over the disputed territory on the basis of its physical presence in the area. According to the Minister of State for Defense, Rana Naeem Mahmood, in the first rounds of negotiations in 1986 and 1987, Pakistan had rejected Indian demands for a ceasefire on existing positions, insisting that a mutual force withdrawal to pre-1984 positions must precede any agreement on a ceasefire. In subsequent negotiations, a changed Pakistan stand called for the withdrawal of troops to positions held at the time of the 1972 Simla Agreement, when the Line of Control was demarcated. Dawn, November 3, 
Any agreement that alters the territorial status of the Siachen region to Pakistan's disadvantage would thus be opposed. This explains Pakistan's rejection of Indian proposals for authentication of actual ground positions prior to a withdrawal or the delineation of the Line of Control beyond NJ 9842 along existing ground positions in the Siachen region. ${ }^{42}$ There would, moreover, be considerable internal opposition to any settlement without adequate safeguards-political and technological-to ensure that the disputed region does not become vulnerable to Indian encroachments in the future.

\section{Taxonomy of Agreements}

Continuous negotiations have been held to contain and resolve the conflict ever since the outbreak of hostilities. As early as 1984 and 1985, flag meetings were held, with little success, between Indian and Pakistani sector commanders. Since January 1986, several high-level talks have been held between Indian and Pakistani defense and foreign secretaries as well as senior military personnel, reflecting their desire to reach a peaceful and negotiated settlement. ${ }^{43}$ In 1989 and once again in 1992, the two countries came close to a resolution of the dispute.

At the fifth round of talks between Defense Secretaries in June 1989, an understanding was initially reached to resolve the dispute. According to the joint statement issued at the conclusion of talks, "There was agreement by both sides to work towards a comprehensive settlement, based on redeployment of forces to reduce the chances of conflict, avoidance of the use of force and the determination of future positions on the ground so as to conform with the Simla Agreement and to ensure durable peace in the Siachen area." The joint statement stated that, "The army authorities of both sides will determine these positions." 44

At the sixth round of the Defense Secretary talks in November 1992, with the assistance of military experts, an India-Pakistan agreement was reportedly reached that envisaged (1) the mutual withdrawal of troops from key passes to new positions, and (2) the creation of a "zone of complete disengagement" as a result of troop disengagement and redeployment. The delineation of this area of "peace and tranquillity" would be "without

1987; The News, August 23, 1992. See also Dr. Maleeha Lodhi, "India flunks the Siachen test," The News, November 30, 1992.

${ }^{42}$ Pakistan is equally concerned that India will use the pretext of redeployment to station its troops in positions which would be more easily defensible in terms of logistics, altitude and terrain. Abdul Waheed Husaini, "Confusion mars Indo-Pak talks on Siachen," The News, November 5, 1992.

${ }^{43}$ In the joint statement issued at the conclusion of Defense Secretary-level talks in June 1986, the two sides expressed their resolve to "find a negotiated settlement of the Siachen issue in accordance with the Simla Agreement." The Pakistan Times, June 15, 1986. Similar statements have been issued at subsequent meetings.

${ }^{44}$ Dawn, August 24, 1992; The Hindustan Times, June 18, 1989. 
prejudice" to the known position of either side. The agreement also reportedly included pledges by both states to refrain from reoccupying vacated positions. ${ }^{45}$

No new positions would be occupied in the designated zone nor would any "activity"civilian or military - be allowed within the designated zone. Time schedules for disengagement and redeployment were to be worked out to the "mutual satisfaction" of both sides, followed by the formation of a joint commission that would be responsible for "delineation of the Line of Control beyond NJ 9842." Until the area was formally delineated, monitoring mechanisms would be devised to prevent the occurrence of violations. Reportedly, either side could resort to "any means," including the use of force, in the event of a violation of these commitments. ${ }^{46}$

The two countries, however, not only failed to implement these tentative agreements, but one or the other side denied that any tangible agreement had been reached on either occasion. ${ }^{47}$ The difficulty in reaching or implementing any mutually agreeable proposal was due to a number of factors, ranging from domestic political constraints to differences over the determination of redeployment positions, the demarcation of the proposed demilitarized zone, and ensuring the inviolability of such a zone. ${ }^{48}$ The significance of the understandings reached in 1989 and 1992 cannot, however, be understated since they identify potential areas of agreement and discord in any future agreement of the Siachen dispute.

\subsection{A Potential Settlement of the Siachen Dispute}

With the resumption of the India-Pakistani dialogue in 1997, as a result of renewed efforts by the Indian and Pakistani governments to improve bilateral relations, the Siachen dispute is once again on the formal agenda of ongoing talks at the foreign secretarial level. While the outcome of these negotiations depends on complex, intertwined, external and internal determinants, a future understanding of the dispute could take any of the following shapes: (1) an accord to de-escalate hostilities; (2) an understanding to disengage military forces, or (3) an agreement to demilitarize the area.

This taxonomy does not imply that the three types of potential agreements would necessarily be reached in sequence or even in isolation from one another. An accord on a limited military disengagement would include an understanding on the avoidance or deescalation of hostilities. Should the political will exist, such an agreement could also include, among its objectives, future negotiations on a more comprehensive solution that

\footnotetext{
${ }^{45}$ Atul Aneja, "Siachen Accord Envisages a Thaw," The Hindu, March 28, 1997; The Nation, June 22, 1996.

${ }^{46}$ Atul Aneja, op.cit.

${ }^{47}$ While the Indian government repudiated Pakistani claims of a mutually agreed upon formula in 1989 , Pakistan refused to accept India's version of the November 1992 accord, spelled out in India's January 1994 Non-Paper on Siachen.

${ }^{48}$ Zafar Abbas, "In From the Cold?" The Herald, April 1997, p. 47.
} 
would involve the demilitarization of the disputed area. Similarly, an agreement to demilitarize the Siachen Glacier would inevitably include the de-escalation of hostilities and the disengagement of troops. It is not necessary that separate accords for either a cessation of active hostilities or the disengagement of military forces would precede an agreement to demilitarize the region.

Each type of agreement and its conflict management or conflict resolution features will depend, moreover, on several broad principles or pre-conditions. Thus levels of mutual trust and confidence and/or mutuality of interests will determine both the nature and the parameters of any potential agreement. Another important precondition is the degree of political will on the part of authoritative decision-makers to reach a peaceful, negotiated settlement of the dispute, including their demonstrated ability or desire to avoid intractable issues.

\subsubsection{De-Escalation Of Hostilities}

The primary objective of such an accord would be to reduce the chances of conflict, ending the active hostilities in the Siachen Glacier region. Such an agreement would include several conflict-management mechanisms. The features of the accord could specifically include restrictions on any quantitative increases in weaponry, and an agreement to refrain from aggressive behavior such as offensives to occupy new territory or to dislodge rival troops. The agreement could also prohibit either side from fortifying its presence in the disputed region through the induction of new military units.

Such an agreement would require confidence building measures such as:

- prior notification of troop rotation

- prior notification of flights or convoys providing logistical support

- a hotline and regular meetings between sector commanders to prevent an increase in tensions or fo end an outbreak of fighting

- observation pusts for monitoring the cease-fire accord.

\subsubsection{Disengagement Of Military Forces}

An agreement on military disengagement could incorporate many of the clauses of an agreement specifically aimed at de-escalating hostilities, including confidence building measures such as prior notification of overflights and flag meetings between Indian and Pakistani sector commanders. Such an accord would, however, move from conflict management to conflict resolution since it would demonstrate the willingness of both parties to find a more comprehensive solution to the dispute. It could also serve as a continuum from cease-fire to demilitarization should the political will exist. 
Relocating troops to minimize the chance of conflict implies (1) gradual reductions of forces in forward positions and (2) an incremental dismantlement of forward pickets and observation posts. Forces would then be redeployed and repositioned in agreed areas. Other measures could include a limitation on overflights. While artillery batteries at the various posts and positions could remain in place, an agreement for military disengagement could envisage gradually downgrading weapons systems, including removing sophisticated military systems such as surface-to-air missiles. ${ }^{49}$

A decision could also be made to refrain from airborne or directed attacks, accompanied by the withdrawal of anti-aircraft batteries. Military observers, joint patrols and other appropriate mechanisms could be used to monitor the accord and to verify agreed levels of military disengagement, including redeploying troops to designated positions and downgrading military equipment.

\subsubsection{Demilitarization Of The Area}

The demilitarization option is the most comprehensive solution for the Siachen dispute. It would require, as essential preconditions, an immediate cessation of hostilities and the prevention of any potential reoccurrence of armed conflict. The creation of a demilitarized zone would cause the complete withdrawal of all military presence on and in the environs of the glacier. Such a withdrawal would be accompanied by the destruction of bases, pickets, and observation posts, the removal of all military hardware from the disputed area, and a prohibition on aerial patrolling and reconnaissance by either side. ${ }^{50}$

The agreement would also include a commitment on both sides to refrain from reoccupying vacated positions. Another confidence building measure could be the use of hotlines between force commanders as well as senior personnel at military headquarters, including Directors-General of Military Operations. Above all, an appropriate regime of monitoring technologies and verification procedures would be identified and instituted to ensure the viability of the accord.

\section{Verification Options}

The phrase "Trust but verify" has been implicit to all arms control agreements since it entered the international security lexicon during the Reagan-Gorbachev years. The theory and practice of verification since the mid-1980s suggests that the stability of a bilateral, regional, or international security agreement depends on how it is verified. ${ }^{51}$

\footnotetext{
${ }^{49}$ Both sides have deployed surface-to-air missiles in the area.

${ }^{50}$ While its access through several routes to the GLACIER area will enable Pakistan to remove its heavy weaponry by land, India might be forced to destroy artillery guns and ammunition that had been paradropped to its positions. Pravin Sawhney, "Siachen Is a Myth." India's Defense: Ten Myths That Have Shaped The Image (Royal United Services Institute, London, forthcoming), p. 10.

${ }^{51}$ See, for example, Gloria Duffy, "Compliance with Arms Control Agreements: What to Look For," Shai Feldman, ed., Confidence Building and Verification: Prospects in the Middle East (Westview Press,
} 
This section examines available verification options for ensuring the stability of a future India-Pakistan agreement on Siachen. Three conceptual dimensions of verification are discussed. First, alternative levels at which verification can be accomplished are classified and their associated attributes discussed. Then, alternative measures by which verification might be sought at the various levels are identified. Finally, implications of alternative verification options for agreement stability are analyzed.

\subsection{Verification Levels}

At least four levels of verification can be conceptualized in the context of Siachen. These include the use of national means as well as three levels of bilateral cooperation: minimal, moderate, and extensive. If verification is done by national means, data would be unilaterally obtained by India and Pakistan and kept confidential. Because data would be gathered without the other side's consent, permissive intrusiveness would be minimal. Similarly, cooperation in the collection and sharing of data would also be minimal due to concerns about compromising national intelligence sources. This would complicate mutual compliance assurance, because each side's national means would be shrouded in secrecy. Thus the potential of national means of verification for building mutual IndiaPakistan confidence would be extremely low. However, verification by national means would not require building domestic support in either country.

At a bilateral minimal level of verification, data unilaterally obtained by India or Pakistan might be occasionally shared with the other, either to substantiate an allegation of noncompliance, or to reassure the adversary about one's own compliance. This level of verification may also involve limited cooperation in the collection of data without extensive sharing of information. Refraining from camouflaging military equipment would be an example of this type of limited cooperation. However, neither India nor Pakistan would have much reason to trust the data provided by the other, and verification would depend primarily on national means. Thus, bilateral minimal verification would involve low levels of permitted intrusiveness, cooperation, and data sharing, and would result in relatively low mutual compliance assurance. The confidence building potential of this level of verification also would be relatively low, but because of its virtually nonintrusive nature, it would require minimal domestic support in either India or Pakistan.

A bilateral moderate level of verification would involve moderate cooperation between India and Pakistan in sharing data obtained through the use of similar if not identical verification measures. This type of verification would require higher levels of permitted intrusiveness, cooperation, data sharing and compliance assurance, and would offer higher confidence building potential in return. However, the intrusive nature of bilateral

Boulder, Colorado, 1994), pp. 103-114. See also Patricia Bliss McFate, "Three Interfaces: Regional and International Stability; Confidence-Building and International Verification; and the United Nations and Regional Organizations," J. Marshall Beier and Steven Mataija, Verification, Compliance and Confidence Building: The Global and Regional Interface (Centre for International and Security Studies, York University, Toronto, 1996), pp. 75-85. 
moderate verification may cause public opposition. Thus, the success of the respective governments in building up the required domestic support would be an important factor in considering this level of verification.

Finally, comprehensive cooperation in obtaining and sharing data is the hallmark of the bilateral extensive level of verification. This level would involve employing similar verification measures by both India and Pakistan, and it would also require extremely high levels of permitted intrusiveness, cooperation, and data sharing. Indeed, both states would expect to receive the same kinds of data provided on an equal basis from virtually identical sensors. Thus, bilateral extensive verification would be characterized by high mutual compliance assurance and would have high potential for building confidence. However. domestic support would become more important in the decision of both governments to agree to this highly intrusive level of verification. Public support for bilateral extensive verification would likely occur only if the agreement were perceived to be in the national interests of both India and Pakistan.

Agreeing about the appropriate level of verification is just as important as reaching an agreement on the dispute itself. In addition, cooperative verification, no matter how extensive. does not replace the need for information from national means.

\subsubsection{Intrusiveness and Compliance Assurance}

Multiple verification measures can operate at each of the verification levels previously discussed. Each verification measure has inherent degrees of intrusiveness and compliance assurance. Intrusiveness has two different dimensions:

- sovereignty. or the degree to which some verification measure requires permissive cooperation from the parties to the agreement.

- sensitivit! of the information being gained from the monitoring applications.

Aerial overtlights illustrate both dimensions. There is the aspect of permitting observational llights into the sovereign airspace of participating states, but there is also the aspect of the resolution of the technologies employed and the degree of sensitive information the! can collect.

A rather different example is remote sensing by satellite that requires no permission from any country to be operated from space, but has the capability of detecting sensitive activities such as weapons development or radio communications. Remote sensing by satellite may not infringe on the legal sovereignty of the observed state, but might be considered quite intrusive if it causes that state to modify operations (such as limiting hours of operation or requiring underground facilities) to prevent observation. Thus, intrusiveness is not always a function of cooperation or permission.

The second conceptual point concerns the relationship between intrusiveness and compliance assurance. While they are usually directly related, they do not necessarily 
have a cause-and effect-relationship. Intrusiveness does not always result in compliance assurance. Thus, it is important not to assume that a verification measure must be intrusive to be effective, or conversely that a verification method that is intrusive is necessarily effective.

Verification measures should be associated with verification levels at which they can be most appropriately utilized. In the context of the Siachen conflict, India and Pakistan would have to weigh the costs of intrusiveness of each type of verification measure against its benefits of compliance assurance in order to identify and select an appropriate package of verification measures to be applied at the agreed verification level.

\subsection{Verification Measures}

The first type of verification measures are declarations and notifications, which are usually made through documents, meetings, and hot lines. In the Siachen context, these measures would involve communication between India and Pakistan to inform each other of intended actions such as troop movements, military exercises, and flights that could appear to be threatening. These unilateral transparency measures could build mutual confidence. Intrusiveness would be very low because of their unilateral nature, and they would provide very little compliance assurance. Over time, they could contribute to confidence building.

At the next level, verification by technical means involves employing various types of devices, such as sensors and associated technologies, and interpreting the data they generate. The following lists available verification technologies:

1. Aerial sensing - Aerial sensing methods could employ photographic and video cameras, both visual and infrared, and radar. The level of intrusiveness of sensors placed on aircraft would depend on several factors, including which country owns and operates the aircraft, whether the flight is in foreign airspace or not, the exact flight path of the aircraft, the altitude of the aircraft, the capability of the sensors on board, who is receiving the data from the sensors, and how data is transmitted. Depending on the combination of these factors, aerial sensors could be moderately to highly intrusive and provide moderate to high compliance assurance.

2. Satellites - Satellites can also carry visual and infrared photographic cameras and radar. However, unlike aircraft, orbiting satellites are outside the sovereign jurisdiction of all states, which reduces the intrusiveness of satellite sensing as a verification measure. Nevertheless, remote sensing from satellites can provide high compliance assurance. Remote sensing data from commercial satellites, such as the French SPOT, the Russian KVR-1000, the Indian IRS-C and the Canadian RADARSAT, could be purchased by either India or Pakistan at relatively low prices. However, this application has limitations, which will be discussed in greater detail in the next section. 
3. Ground Sensors - Ground sensors include seismic, acoustic, magnetic, infrared, thermal, and radar devices. They can (1) monitor the movement of troops or equipment along access routes to deployment areas; (2) detect the provision of aerial supplies to forward positions; or (3) monitor base camps away from the glacier. Ground sensors would be more intrusive than aerial or satellite sensors, but they would provide high compliance assurance. The degree of intrusiveness of ground sensors would depend on several factors, including which country had placed the sensor, where the sensor had been placed, who was receiving data from the sensor, and how the data was being transmitted.

4. Video and Optical Sensors - Cameras can be much more intrusive than other ground sensors. While all data generated by ground sensors, whether optical or non-optical, would be subject to interpretation by both countries, photographs tend to be less ambiguous than data from some other types of ground sensors. In the Siachen context, video and optical sensors could supplement other sensors by providing a visual assessment of activity. Though ground-based video and optical sensors can be highly intrusive, the compliance assurance they may provide can be just as high.

5. Tags and Seals - Artillery pieces could, for example, be tagged and their removal verified by joint Indian and Pakistani inspection teams at specified inspection sites in the vicinity of the glacier. The intrusiveness is very high, because India and Pakistan would give each other access to their hardware. However, tags and seals would also provide very high compliance assurance.

6. Inspections - Potentially one of the most intrusive verification measures for India and Pakistan would be ground and aerial inspections of their forces, equipment, and force dispositions by the other side. Baseline inspections could verify the situation on the ground prior to the signing of an India-Pakistan agreement on Siachen. Routine inspections would be more intrusive and would involve periodic inspections of specified facilities and camps on either side. Elimination inspections could verify the disabling and destruction of hardware prohibited by an India-Pakistan agreement. These three types of inspections represent increasing levels of intrusiveness, but could provide high levels of compliance assurance.

Two other types of inspections also might be possible in the context of a Siachen agreement. If challenge inspections were authorized, both countries could mount inspections on demand with minimum notice. Continuous inspections would involve the permanent presence of Indian and Pakistani inspectors in each other's facilities. Both inspection regimes have extremely high levels of intrusiveness and compliance assurance.

Clearly, India and Pakistan would have a wide array of verification measures with different degrees of intrusiveness available to them to verify a Siachen agreement. However, not all the verification measures discussed above would be suitable to Siachen. Altitude, weather, and terrain on the Saltoro Range and the Siachen Glacier will put any technology to a rigorous test. For instance, the degree to which acoustic, seismic, and other ground sensors would be able to function when buried under several meters of snow 
would need to be evaluated. Many parts of the glacier and the Saltoro Ridge are avalanche-prone because of the steep gradient. Thus, ground-based sensors could be lost and damaged frequently and would require regular replacement. Since blizzards reach speeds of 300 kilometers per hour on the Saltoro Range, it is uncertain whether sensors mounted on towers and masts would be able to withstand such tremendous wind speeds. Some existing sensors may not be able to withstand temperatures as low as -40 degrees Celsius. ${ }^{52}$ Radars with domes may present a viable alternative for short-range air-space monitoring. The ability of sensors to function in the glacier environment can be determined only through rigorous on-site or environmental testing, and it could be necessary to specially design suitable verification equipment.

Since the disputed area is perennially snow-covered, tests would be needed to determine if commercial satellite imagery would be effective, given the large expanses of white background in the images. RADARSAT images of the disputed area show the terrain well but the current resolution of the images is not good enough for the application of monitoring low-level military activity ${ }^{53}$ Finally, given the uninhabitable nature of the disputed area, it is not just technical measures that would be subject to all manner of limitations. The deleterious impact of extreme altitude, weather, and terrain on the human body would make a continuous inspection regime highly improbable. Thus, the harsh conditions on the glacier will pose special challenges to any verification regime.

\footnotetext{
${ }^{52}$ Geophone sensor SM-6, manufactured by Sensor Nederland bv has an operating temperature range -40 to 100 degrees Celsius.

${ }^{53}$ Thomas Budge, Earth Data Analysis Center, University of New Mexico, Albuquerque, New Mexico.
} 
VERIFICATION APPLICATIONS

\begin{tabular}{|c|c|c|c|}
\hline $\begin{array}{l}\text { Verification } \\
\text { Measures }\end{array}$ & De-escalation & Disengagement & Demilitarization \\
\hline $\begin{array}{l}\text { Declarations } \\
\& \text { Notifications }\end{array}$ & $\begin{array}{l}\text { Documents } \\
\text { Meetings } \\
\text { Hot lines }\end{array}$ & $\begin{array}{l}\text { Documents } \\
\text { Meetings } \\
\text { Hot lines }\end{array}$ & $\begin{array}{l}\text { Documents } \\
\text { Meetings } \\
\text { Hot lines }\end{array}$ \\
\hline \multirow[t]{5}{*}{$\begin{array}{l}\text { Technical } \\
\text { Monitoring }\end{array}$} & & $\begin{array}{l}\text { *Aerial Sensors } \\
\text { - photography } \\
- \text { visual } \\
- \text { infrared } \\
\text { - video } \\
\text { - radar }\end{array}$ & $\begin{array}{l}\text { Aerial Sensors } \\
\text { - photography } \\
- \text { visual } \\
- \text { infrared } \\
\text { - video } \\
\text { - radar }\end{array}$ \\
\hline & $\begin{array}{l}\text { Commercial Satellite } \\
\text { - photography } \\
-\quad \text { visual } \\
-\quad \text { infrared } \\
\text { - radar } \\
\end{array}$ & $\begin{array}{l}\text { Commercial Satellite } \\
\text { - photography } \\
- \text { visual } \\
- \text { infrared } \\
\text { - radar } \\
\end{array}$ & $\begin{array}{l}\text { Commercial Satellite } \\
\text { - photography } \\
- \text { visual } \\
\text { - infrared } \\
\text { - radar } \\
\end{array}$ \\
\hline & & $\begin{array}{ll}\text { Ground Sensors } \\
\text { - } & \text { seismic } \\
\text { - } & \text { acoustic } \\
\text { - } & \text { magnetic } \\
\text { - } & \text { infrared } \\
\text { - } & \text { thermal } \\
\text { - } & \text { radar } \\
\end{array}$ & $\begin{array}{l}\text { Ground Sensors } \\
\text { - } \quad \text { seismic } \\
\text { - } \text { acoustic } \\
\text { - } \text { magnetic } \\
\text { - infrared } \\
\text { - thermal } \\
\text { - } \text { radar } \\
\end{array}$ \\
\hline & & \multirow[t]{2}{*}{$\begin{array}{l}\text { *Video and Optical } \\
\text { Sensors }\end{array}$} & $\begin{array}{l}\text { Video and Optical } \\
\text { Sensors }\end{array}$ \\
\hline & & & Tags and Seals \\
\hline Inspections & ${ }^{*}$ Baseline & $\begin{array}{l}\text { Baseline } \\
\text { Routine } \\
\text { Elimination }\end{array}$ & $\begin{array}{l}\text { Baseline } \\
\text { Routine } \\
\text { Elimination } \\
\text { Challenge } \\
\text { Continuous } \\
\end{array}$ \\
\hline
\end{tabular}

*Verification measures dependent on terms of agreement

\subsection{Verification and Agreement Stability}

The purpose of verification is to assure compliance, which is necessary for agreement stability. The stability of an India-Pakistan agreement on Siachen would depend on how comprehensive the agreement is and how extensively it is verified. According to the taxonomy devised in the previous section, the least extensive agreement on Siachen would be a de-escalation of hostilities between India and Pakistan. A de-escalation agreement that the two countries verified solely by national means is likely to be 
unstable, because verification methodologies that depend entirely on national means can increase mutual distrust, although national means probably would be extensively utilized by both countries to verify a de-escalation agreement.

Likewise, a de-escalation agreement that relies on an occasional sharing of information might also be slightly unstable due to lack of trust. However, a de-escalation agreement between India and Pakistan, supported by a moderately intrusive verification arrangement, would be much more likely to endure and build confidence. Lastly, it would be inappropriate to verify an India-Pakistan de-escalation agreement at the bilateral extensive level, because extremely intrusive verification in a situation of minimal mutual agreement would likely contribute to tension.

Thus, in the context of a de-escalation agreement, if prior notification of troop rotation and flights or convoys providing logistical support is agreed upon, verification could be ensured through data exchanges via flag meetings and hotlines. Compliance of a deescalation agreement could also be ensured through baseline inspections, satellite imagery, and radar.

An agreement between the two countries that was aimed at disengagement of military forces would be far more extensive than a de-escalation agreement, and would therefore require a much more extensive level of verification. Verification of military disengagement solely by national means would be highly unstable, and could lead to a lack of confidence in the agreement. Nevertheless, national means would be used by India and Pakistan to supplement a bilateral arrangement to verify military disengagement.

A military disengagement agreement that could only be verified at the bilateral minimal level, with the occasional sharing of unilaterally-obtained information, also would be unstable. However, a military disengagement agreement between India and Pakistan that depended on verification at the bilateral moderate level would be much more stable. Bilateral extensive verification of a military disengagement agreement between India and Pakistan would be inappropriate. As long as Indian and Pakistani forces remain in the area, an extremely intrusive verification arrangement would lead to tension and could easily threaten agreement stability.

Thus, as in the case of de-escalation, commercial satellite imagery could be used to assure compliance. In addition, because of the higher levels of intrusiveness associated with this kind of agreement, aerial sensing could be used, for example, to verify a gradual reduction of forces and equipment in forward posts as well as ground resupply. A limitation on unauthorized flights could be most effectively verified by radar and acoustic and seismic sensors. A slightly more intrusive agreement might permit the use of video and optical sensors to supplement other ground-based sensor systems. Finally, baseline, routine, and elimination inspections could be used to verify the incremental dismantling of forward posts and the gradual downgrading of weapons systems. 
The most extensive India-Pakistan agreement on Siachen would involve demilitarization of the area. A Siachen demilitarization agreement based solely on verification by national means would be extremely unstable and could easily collapse. Thus, it would appear unlikely that national means verification, based on technical and human intelligence, could by itself induce agreement stability at any level. Nevertheless, national means would be used to supplement more intrusive and cooperative levels of verification.

A demilitarization agreement based solely on bilateral minimal verification, with hot lines, flag meetings and the occasional sharing of information obtained from nationally owned and operated sensors, would also be unlikely to bolster confidence and mutual trust between India and Pakistan and would be highly unstable. A moderately intrusive verification arrangement between the two countries could significantly strengthen a demilitarization arrangement and lead to agreement stability. Nevertheless, bilateral moderate verification, incorporating cooperative monitoring through ground sensors and baseline, routine, and elimination inspections, would not be sufficiently extensive for a Siachen demilitarization agreement.

For such an arrangement to be extremely stable and successful, cooperative monitoring at the bilateral (extensive) level may be necessary to assuage concerns that the vacuum created by the complete withdrawal of troops and equipment could not be exploited by the other side. This package of verification measures, in addition to the minimal and moderate measures identified above, might include cooperative monitoring through aerial, video, and optical sensors as well as tags and seals. It could also require challenge and continuous inspections.

Aerial sensing and commercial satellite imagery could, for example, be used to verify the withdrawal of all troops, the destruction of all military bases and the removal of all military hardware. Optical, video, thermal, and motion sensors could be deployed to observe activity in the abandoned camps and posts. Acoustic and seismic sensors and radar could be used to monitor prohibition on unauthorized overflights.

Any stable agreement of the Siachen dispute, whether it involves the de-escalation of hostilities, the disengagement of military forces, or demilitarization, requires an appropriate fit between agreement provisions and verification requirements. Thus verification knowledge and expertise would play a vital role in ensuring the stability of any future agreement of the Siachen dispute.

\section{Freezing the Fighting: The Logic for Change}

After years of hostilities, neither India nor Pakistan are any closer to achieving their stated objective of acquiring control over the disputed territory through the use of force. Policy makers in both states have begun to examine the possibilities of a negotiated agreement, partly as a result of the military stalemate and partly because of the mounting costs of the conflict in terms of lives and money. The Siachen dispute covers a territory 
of little strategic importance for either state, while it serves as yet another irritant in the uneasy relationship between India and Pakistan.

A peacefully negotiated settlement of the Siachen conflict appears especially logical since the glacier's inhospitable terrain will continue to deter Indian and Pakistani attempts at acquiring military predominance. At the same time, an agreement on Siachen will not impinge, either militarily or politically, on the position of either side in the resolution of their other, more major differences. A settlement of the dispute would, however, reduce bilateral tensions, thereby improving the climate for future steps towards peace. Specifically in the context of the Siachen dispute, even a policy option that merely reduces hostilities would serve as a first step towards the conclusion of a more comprehensive agreement.

Should India and Pakistan succeed in reaching an agreement on Siachen, their ability to implement such an accord will depend, above all, on the political will of their respective leaderships. At the same time, the application of pertinent verification measures would assist policy-makers in their task of ensuring agreement stability and compliance. If the appropriate verification mix is not identified, provisions could be incorporated into a future agreement that could not be adequately verified, reducing the prospects of agreement stability. Thus, the ability of India and Pakistan to reach a durable accord of the Siachen conflict will be greatly enhanced by an understanding of the complex interrelationship between potential negotiated terms and adequate knowledge of verification methodologies. 


\section{About the Authors}

Dr. Samina Ahmed is a specialist on South Asian security and a free-lance journalist. She has a master's degree in International Relations and a Ph.D. in Political Science from the Australian National University. Dr. Ahmed has considerable research experience and has published extensively on South Asian security issues. Her publications include the co-edited book, Pakistan and the Bomb: Public Opinion and Nuclear Options, as well as several book chapters and articles in academic journals and the print media.

Dr. Varun Sahni is Associate Professor in International Politics at Jawaharlal Nehru University, New Delhi, and Professor Investigador en Estudious Internacionales, Centro de Investigacion y Docencia Economicas, Mexico City. Dr. Sahni received both his master's degree in Latin American Studies and D. Phil. in politics from the University of Oxford. 


\section{Distribution}

350 MS 1373 CMC Library, 5341

1 MS 9018 Central Tech Files, 8940-2

2 MS 0899 Technical Library, 4916

2 MS 0619 Review \& Approval Desk, 12690 for DOE/OSTI 
Freezing the Fighting:

This page intentionally left blank. 